\title{
Civilizational deadlock of the economy of growth
}

\author{
Elena Alatartseva ${ }^{1 a}$, Robin Matthews ${ }^{2}$ \\ ${ }^{1}$ Tomsk Polytechnic University, Institute of Humanities, Social Sciences and Technologies, Tomsk, 634050, Russia \\ ${ }^{2}$ Kingston University, Kingston upon Thames, Surrey KT1 1LQ, UK
}

\begin{abstract}
The key topic of the paper is determined by the crisis situation of the nowadays economic model. Capitalism is the dominant economic form in the global economy. Varieties of capitalism exist ranging from state capitalism to neo liberalism but all are pervaded by a dominant theme, an egocentric economy model or ego-economics. This model is underlain by postulates of the need for a continued growth spurred by end-use. The realisation of this model is provided by monetary approaches and stimulation of consumer demand as the main driver of economic growth. The key tools for stimulating demand in this model of economy are competition, information impact on the consumer consciousness and choices, the massive accessibility of credit, the massive accessibility of financial markets and financial instruments, the actualisation of passive incomes as opposed to creative labour, and other degradation triggering factors. The crowning part of this model is the debt economy of consumption of societies of individualists who do not share traditional systems of values but are guided by illusory, temporary, shortterm objectives. Thus, the egocentric economy model established dominance in relation to the ecological economy model, exposing a bulk of contradictions in principles underlying the system and promotes unsustainability. The future turned out to be in jeopardy... The paper contrasts ego-economics and ecoeconomics, traces of the emergence of the first one and the need for the second one as a necessary condition for long-term sustainability.
\end{abstract}

\section{Introduction}

The deep socio-economic and socio-political upheaval taking place all over the world today both at the global and local levels is conventionally referred to with the use of such a generalized term as "crisis". However, this crisis has a quite clear outline - this is a crisis of the socio-economic model of the structure of society oriented towards a constant growth of economy. Moreover, this refers to both the global-scale economy (macroeconomics) and national economies (microeconomics). In our discourse, we proceed from the premise that economy is the basis of the life of society, because it is a system of essential public relations through which goods are created that bring utility to people. Economy from this viewpoint was described by the Greek thinker Xenophon who regarded economy as the art of household management which is known to us today as "Oeconomicus" [1]. Needs of people naturally increase and change in the course of the development of human society both as a whole and at the level of national societies within the limits of individual states, stemming from the increase in the number of people and their life expectancy and from the development of science and technology. It is clear that this change in needs takes place in quantitative and qualitative terms. The quantitative growth of needs is conditioned by a simple growth of the population of the planet and by the emergence of completely new needs that previously were of little popularity or even unknown. At the same time, these same factors can lead to qualitative changes in the structure of needs, too. Thus, for example, medicine and education as spheres of activity, as branches of science creating real goods to people, exist for, at least, several millennia. However, human needs for goods created by medicine and education came to be perceived by the society as natural, essential, necessary, and basic not so long ago, approximately in the late 1930 s. In contrast to this, the need in mobile communication, in access to the Internet, and in using computer technology represents a completely new type of needs which did not even exist in the late 1960s - early 1970s and which have now added on to the category of natural human needs. It is actual even for the older generation, which previously did not know about such opportunities and had no 
corresponding need $[2 ; 3]$. It is clear that the desire of people to meet their natural needs creates a demand for the corresponding goods, which, in conjunction with population growth, leads to both economic development and economic growth. Setting aside the analysis of the structure and the socio-economic content of the indicators, as well as the influence of inflation processes, let us have a look at the indicators of the population size and the gross domestic product, which is currently used as the basic measurement of economic growth. According to the OECD, in 1960, the world population was slightly above 3 billion people, and the world GDP (with a certain extent of error) was less than 1.5 trillion US dollars, while in 2005 the same indicators (also with some extent of error) were more than 6.5 billion people and more than 45 billion US dollars, respectively.

\section{Economy of development, or an ecological model of economy in contrast to economy of growth, or an egocentric model of economy?}

\section{What the ecological economy is and why we talk about}

The relationship between the development of society and economy at the level of a nation and the world is obvious. The development of society, which manifests in the development of the public, political, cultural, historical, spiritual, moral, social, economic, scientific, and technical aspects of society, inevitably leads to economic development which, in its turn, is a factor initiating and influencing the development of society. The quantitative and qualitative dynamics of needs of society on the global and national scales is undoubtedly a factor of economic development and one of its key indicators. Economic growth is another similar factor and indicator of economic development and it is currently measured by means of such an indicator as the gross domestic product which is both the cause and consequence of the development of needs of people and society. Using this line of reasoning, we, on the one hand, reaffirm the axiom of economic science which states that the main function of economy is the production of such tangible and intangible goods that are aimed at meeting the needs of all members of society and which provide creative stable lives, well-being, and the prosperity of society as a whole and each individual in particular. In other words, the modern economic science proclaims the same role of economy in the life of society as the one proclaimed by the aforementioned Xenophon, - the creation of goods (or, in the terminology of A. Smith, K. Marx, and other researchers - wealth) which provide utility to people. On the other hand, we inevitably come to the conclusion that, as a result, economic growth becomes the indicator of the development of economy aimed at creating goods that bring utility to society which rapidly develops and has its population and the population's needs on the increase. Such a conclusion, theoretically, looks quite logical; however, at the same time, it is very abstract. Real results of the development of economy on the global national scales show otherwise: despite the rapid growth of the population and its needs, despite the increase in the life expectancy of people, despite the social, cultural, scientific and technological development, the world has been facing constant economic crises and, during the recent 50 years, a declining economic growth in terms of the real GDP as adjusted by the inflation rate. For example, according to the report on the index of consumer prices in the USA published in December 2014, during the last 50 years, consumer price index went up by more than 7 times. Thus, if we convert the world GDP of 2005 into prices of 1950, the result will be fairly modest - a little more than 6 trillion US dollars; and a similar presentation of the world GDP of 2014 in prices of 1950 gives a value below 8 trillion US dollars. Moreover, the calculation of real per capita incomes is going to produce an absolute decline. For example, according to the Economics and Statistics Administration of the USA, the average wage of a worker in the USA in 1970 in real terms was higher than a similar wage in 2006 .

But then a logical question arises as to what kind of economic growth the world economy has been demonstrating during the recent half-century and even longer, and why the nowadays economy has faced a severe crisis which modern economists simply characterise as a slowing-down or even decline of economic growth expressed in the GDP indicator?

We believe that, most probably, we deal with a substitution of concepts, causes and consequences, as well as with a metrological insolvency of contemporary macroeconomic and microeconomic indicators. Let us clarify our assumptions.

In the beginning of the article, when talking about the essence and role of economy in the life of people and society, we proceeded from the main purpose of economy - the production of goods that meet the needs of people and society and that bring utility to them. This is a model of economy that realizes organizational and technological approach in its development, the key factors of which are human being, society, individual and social needs, and the spiritual, moral, cultural, historical, socio-political, scientific, technical, and socioeconomic development, all interrelated with the Earth's biosphere. Such a model of economy focuses on the following key bases:

1. How needs appear, what is the structure of the needs, what is the relationship and interdependence of individual and socially significant needs, what is the dynamics of the needs in relation with the development of society, science, and technology?

2. What are the consequences of the production of goods meant to meet these needs, and what are the consequences of meeting these needs (for example, the consequences of the production and horror films, in 
themselves, are environmentally friendly - such a production does no harm to society or to biocoenosis, while the "non-environmental, harmful" consequences of watching these films by people and, in particular, by children, adolescents, or by simply mentally unstable individuals are very hard to be overestimated and quite easy to be underestimated)?

3. What should be the structure of production, and how should production priorities be ranked and volumes of production determined?

4. What technology should be used and what load on natural resources and sources of energy should there be to ensure that, on the one hand, the production requirements are met and, on the other hand, that the environmental safety of production and the balance of the ecosystem are maintained?

Such a model of economy can be conditionally called ecological model of economy or eco-economy. The key criteria of such an economy are human being, goods, needs, and utility. These criteria should serve as measurement and evaluation objectives, and it is they that should be used to assess economic development.

The model does not deny any benefit, gain or personal interest, but it builds them on a different basis. There is no doubt that economic growth will be one of the indicators of economic development in this economy model. However, one should think that the economic growth of eco-economy will not show a linear growth of the GDP and not even the GDP indicator itself (which contains plenty of distortion as it depends on various ways of its calculation and the measurement of intermediate data and parameters, as well as being subject to inflation effects). It should be something else rather a linear indicator reflecting structural changes in economy in terms of production, consumption, and in terms of consequences of the production and consumption. The ecological model of economy is a model of a steady economic development which provides the well-being of nowadays generations and lays the basis for the subsequent development and wellbeing of future generations, while maintaining ecological balance of biogeocoenosis. This is an economy of transformation, which provides economic and environmental security and lays the basis for a crisis-free and steady development. This is an authentic real economy in its essential meaning and functional value.

But what is the difference of the nowadays model of economy from the one described above? One key difference is that the strategic goal, the main function, the main objectives, and the key performance indicators of the nowadays economy is profit as determined by such financial and economic categories as added value, income, profitability, revenue, etc. Another difference is that the key subject of the nowadays economy is not a human as a public, social subject whose needs resonate with the needs of society as a whole, but an individual with their personal interest, personal profit, and personal needs. Such a substantial substitution of concepts leads to a false understanding and interpretation of these objectives and functions of the nowadays economic model. A human, as an object and, at the same time, a subject of biogeocoenosis, is perceived as an integral part of all social and biogeocoenotic processes. A human is the cause, the consequence, the creator, the consumer, and the one who reaps the fruit of his or her own activity. Meanwhile, an individual is opposed to the whole society, the whole ecosystem, and all generations before and after this individual, because the personal and, even more, private interests of the individual prevail over the interests of other individuals and society as a whole. This, for example, is affirmed by the terminology used to describe the categories of property. For example, personal or individual property is different from private property. Such a categorization of things as individual, personal, private, separate, etc. has led to "I" and one's own life becoming something similar to an object of investment, a kind of business, a corporation for the individual. "I" becomes the object of intense work on self-enrichment, maximization of personal individual consumption, and accumulation of wealth. The key mechanism of the implementation of such work in the nowadays model of economy is the competition for markets, for the consumer, for resources, and for everything that contributes to personal individual enrichment [4].

Such a model of economy focused on self-interest was referred to by Aristotle as chrematistics since this model is underlain by the principle of accumulation of wealth. The accumulation of wealth, at all times, was defined as the accumulation of money - gold, silver, or other values which served as money. As the modern economic thought has not changed its standpoint, it is obvious that the main purpose and function of the nowadays economy model is also the accumulation of wealth, with the only change that, in the absence of gold circulation or gold standard, it rests on monetary units or their equivalents and the so-called readily obtainable assets that are easy to convert into money. Continuing with the analogy, in this case, productive labour will be any kind of labour the purpose of which is the creation of the aforementioned kind of "wealth", including labour for the creation of commodities, services, tangible and intangible assets, etc. rather than for the creation of "a good". Note that such simple and clear notions as "a good", "creation of goods" today have disappeared from speech and, all the more, from economic speech, and they sound like anachronisms. This is natural, because, once again, we are dealing with a substitution of concepts. "A good" as a term clearly implies a creative aspect; it conveys the idea of benefit to people and society. And such formalized terms as "commodities", "assets", "things", "objects", "financial instruments" and so forth can be anything at all, because in the nowadays economy model they are of any interest only if they are able to generate money. Including when this is done at the cost of destruction of people and society, by means of causing harm. For example, alcohol is clearly is not a good, but it is a commodity and is a significant part of 
the GDP of the most developed countries of the world. The same can be said about the tobacco industry and about the pharmaceutical industry, the main goal of the latter being to "create" a chronically sick person so that the need for cure would transform into a natural need in medicines, ensuring permanent income to pharmaceutical companies for centuries ahead (the annual growth rate of the world's pharmaceutical market for the next 5 years is estimated to be $3-6 \%$ in developed countries and $14-17 \%$ in dynamically developing ones [5]. The industry of primitive entertainments (on the verge of amorality), gambling, and war are also not natural human needs, but they make almost half of the income part of the budgets of developed countries. Such a model of economy can be conditionally called an egocentric model or ego-economy.

The egocentric model of economy, ego-economy or ego-nomy, by its content, goals, objectives, functions, and indicators represents a destructive opposite to the creative and transforming ecological economy model, eco-economy or eco-nomy in its authentic meaning. That is exactly why it is necessary to exclude the substitution of concepts: more than 100 years ago Kozma Prutkov said: "Many things are incomprehensible to us not because our comprehension is weak, but because those things are not within the frames of our comprehension." Using the term "eco-nomy", society receives a signal that the goals, objectives, and functions of economy are of a progressive, creative nature and are aimed at creating goods both for society as a whole and for each person in particular, in his or her consensual agreement with social priorities. Using the term "ego-nomy", society receives an unambiguous signal that private, individual interests are above anything else, and the financial and business activity of society pursues only one goal which it considers significant - individual gain, and the main function of the mentioned activity of society is subject to this goal. Such a model of economy may, at the same time, be creative, but only in part. And practice, being the criteria for truth, shows this very clearly. In real life, "ego-nomy" is a destructive model of economy, because, while declaring ideas of sustainable development of mankind [6], it relies either on direct deceit and fraud, or on indirect ones, or on the redistribution of goods or wealth in favour of key subjects of such a model of economy. Let us remember the words by T.J. Dunning which he said as far back as in the 19th century and which were repeated by K. Marx in his work "Capital": "With adequate profit, capital is very bold. A certain 10 per cent will ensure its employment anywhere; 20 per cent certain will produce eagerness; 50 per cent positive audacity; 100 per cent will make it ready to trample on all human laws; 300 per cent, and there is not a crime at which it will scruple, nor a risk it will not run, even to the chance of its owner being hanged. If turbulence and strife will bring a profit, it will freely encourage both. Smuggling and the slave-trade have amply proved all that is here stated." [7].
Modern means of deriving benefit are more sophisticated but not less destructive or criminal. The pharmaceutical industry, which is intended to ensure the health of people, in reality contributes to their chronic poor health. The military industry, which is intended to ensure the defence capability of states and survival in geoclimatic catastrophes, is interested in initiating military conflicts and wars. Let us have a look at the following figures: the US Congress approved the military budget for 2015 in the amount of $\$ 585$ billion US dollars, which is almost $4 \%$ of the GDP of the US and twice as much as the combined military budgets of all the other countries of the world and 7.3 times more than the military budget of Russia for 2015. Nuclear energy, which can solve the problem with the depletion of energy resources, at this stage is a direct threat of nuclear war and environmental catastrophe. Scientific and technological progress, which is intended to serve the humanity, has put mankind on the verge of catastrophe. The financial system that provides a systematic structural movement of cash revenue at different levels of economy is at the service of key participants of the financial world [8; 9]. The UN recommendations, released in 1993, for a possible inclusion of the income of shadow economy and the income from the production and turnover of prohibited goods and services, such as drug trafficking, the trade of human organs, prostitution, slave trade, etc., in the GDP in order to demonstrate economic growth was a blatant fact which only revealed the appalling consequences of such a model of economy. Today, at the end of 2015, in the century of "triumph of the human genius", the administration of Angela Merkel, Germany being the key EU economy, is seriously discussing these matters, grounding such an agenda by the argument that, if such proceeds exist and the state can do nothing about this fact, why not use this situation for the state itself to earn "bonuses" in the form of a positive economic growth, the growth of the GDP, the maintenance of the status of a stable, powerful, and dynamic economy, higher credit ratings, investments, expansion of major corporations, etc. For any sensible person this can mean only one thing - ego-economy has reached its limits to growth, found itself in a deadlock, and exhausted the possibilities of development. Moreover, this means the depletion of sources of meeting individual selfish interests in the economy of private benefit. The Nobel laureate of the year 2015 Angus Deaton stated straightforwardly that the system of the world economy, the focal point of which is the interests of selected groups and elites, is doomed to fail, because its institutions hinder the growth; moreover, they are opposed to it [10].

Direct evidence of this is the current state of the world economy and all national economies, including those of the so-called developed countries. The rapid degradation of the world and national economies is a direct consequence of the realisation of the egocentric model of economy during the last century: it reached its culmination in the late 1980 s - early 2000 s and is now 
rapidly rolling down. The succession of crises that affected national economies and the world economy as a whole over the last century is a proof of that.

The foundation of economy which provides its steady development rests on the following "three whales" or pillars: people, their needs, and economy as the basis of meeting those needs are primary; social needs have priority over individual selfish ones since social needs provide sustainability, stability, and sovereignty of states; money and money circulation are a tool for the functioning of an economy, economy-related goals, tasks and functions; finance as the system of redistribution of income is a mechanism for managing incomes, funds, reserves, budgets, and money circulation. And it is precisely these foundations that are undermined by "egoeconomy". The priority is that of private profit, not of a human being; money has changed from being a tool to being a commodity and has taken priority over real goods (assets); finance has turned into a self-maintained industry functioning independently from economy; and the intensification of production and increase of labour productivity have been replaced by an extensive dynamics of expansion over territories and markets in search for sources of consumer demand and, consequently, new profits. Exactly this situation is the stem of destructive factors, exactly this is the main cause of economic and other crises, including socio-political, spiritual and moral ones; it is this egocentric model of economy that is the dead-end of the development of society, being restricted by the limits to growth [11]. In other words, the self-destruction mechanism was originally put in this model of egocentric economy [12].

The ecological model of economy bears an internal impulse for constant development and, consequently, for growth since it stems from the needs of human beings and society, improving them and creating new ones, which inevitably leads to transformation, progress, and development. This is where its conditional/relative crisis-free nature comes from. The basis of such a model of economy contains a self-reproducing potential for development. And, as a natural result of eco-economy, we observe economic growth. Partially, elements of such an economic model were reflected in the Keynesian model of economic development, which aimed at the recovery and stabilisation of the economy after a severe crisis in the United States in 1929-1933 and at a subsequent steady economic growth at the expense of a full employment of the population, which made it possible to create a constant consumer demand [13]. As regards the egocentric model of economy, economic growth is its end in itself, is its primary cause, because it allows gaining profit. This model of economy can function solely thanks to an external impulse, such as a steady consumer demand for assets which are profitable to produce in the framework of such a model. Besides, this consumer demand must also be financially solvent, that is able to pay. This is because the accumulation of wealth by one party is provided solely by the consumption carried out by another party. And this means that it is not consumer demand that stimulates the development of economy, but it is the desire to gain individual selfish profit that stimulates consumer demand as the main driver of economic growth. By any means, by any ways, at any cost... However, consumer demand in "ego-economy" has a structure completely different from that of consumer demand in "ecoeconomy". The key difference in the structure of consumer demand is that there has happened a shift in demand from the scope of material things to the scope of services and finance. The demand for creative work has been replaced by the demand for passive income, the demand for active ways of spending free time has been replaced by the demand for primitive entertainment, the demand for education has been replaced by the demand for academic degrees, the demand for professional development has been replaced by the demand for career, the demand for a socially significant role and the sense of life has been replaced by the demand for statuses, the demand for cooperation has been replaced by the demand for competition for resources, statuses, and profits, the demand for sufficient well-being has been replaced by the demand for excessive accumulation, etc.. The main tools of the formation of this demand were the massive information impact on the consumer consciousness, on the one hand, and the general availability of credit resources, on the other. It is not income that initially provides consumer demand with financial solvency, but it is promotion of consumer demand that prompts to search for sources of its capacity to pay. At the current stage of the development of society, this process has acquired a global scale and alarming tendencies. As economic observer of Financial Times Martin Wolf said, "Financial liberalisation and financial crises go together like a horse and carriage." Lyndon LaRouche, an American scholar and economist, a public and political figure and a candidate for the post of President of the United States in 1992, in his election speech convincingly showed that contemporary worldwide financial and monetarist policies will inevitably lead to a collapse [14].

\section{Metrological failure of macroeconomic indicators in egocentric economy}

Such a structural disposition of the basic drivers of economic development and economic growth seems to be quite obvious; however, this has been carefully hidden behind the averaged macro- and microeconomic indicators used to assess this development and growth. Such indicators widely used today are the GDP, stock exchange indices, credit ratings, inflation rate, gold and foreign exchange reserves, consumer price indices, indices of business activity, and so forth. But all of these indicators are metrologically inconsistent, because they do not reflect objectively either the phenomena per se or their qualitative and quantitative characteristics (signs), and, besides, they are also based on a defective methodological base of measurement which relies on 
principles of averaging, linear trends, irrelevance of goals, processes, conditions, algorithms, parameters, and indicators. Already in 1990, the Nobel laureate, worldrenowned scientist and economist V.V. Leontyev in his work "The Economic Essay" spoke of the depravity and falsity of a situation when many scientists and analysts refine the tools of analysis of economic processes, phenomena, and conditions, at the same time avoiding explaining the reasons of their appearance and not establishing any cause-effect interrelations and interdependences. They base their conclusions on a system of performance indicators and parameters which describe actual states, and they further use these to build conclusions in respect of trends and future forecasts of, once again, states [15]. "The drawback of the modern economy is not the indifference to practical issues, as many practical men thought, but a complete inoperability of scientific methods using which these issues are attempted to be solved" [16]. The conceptual and metrological insolvency of economic theories, methods, and indicators, as well as their inconsistency with real goals, objectives, and interests of the people and society were talked about by J. K. Galbraith [17] and Lindon LaRouche [14]. Angus Deaton also speaks about the metrological inconsistency of indicators of economy, substantiating his opinion with the fact that they are all averaged and reveal neither the structural characteristics nor the dynamics, and, besides, they are often quite uncertain [10]. Thus, for example, the GDP as an averaged indicator can demonstrate a positive dynamics in its growth, while concealing inflationary processes and showing the increase of prices rather than the growth of production in its structure. In 2014, the Central Bank of Russia, the Ministry of Economic Development, and the Ministry of Finance of the Russian Federation reported, with a great enthusiasm, to the government and the President of the Russian Federation that the inflation rate in the Russian Federation in the year 2013 reached its minimum value for the previous 20 years and amounted to $6.5 \%$. However, the structural analysis of inflation processes in the Russian Federation showed that in 2013 the level of social inflation showing the dynamics of prices for socially significant goods and services reached almost $15 \%$ and came close to critical values. While the GDP growth in the Russian Federation in 2013 showed a positive dynamics, the proportion of material production in its structure was only $39 \%$, which is two times lower than critical values. Besides, the positive dynamics of the GDP was provided by foreign trade turnover, in the structure of which the share of manufacturing industry was only $23 \%$, which is again two times lower than critical values. [18].

Everything above enables us to make an assumption that the currently adopted economic metrological system applied for measuring the state of economy serves only one goal - to justify the progressiveness of the egocentric economy model and to conceal its degradation vector. Until now, the understanding of economic development is based on the terminology of the 20th century, when S. Kuznets gave his explanation to what the contemporary economic growth was which he understood as a faster rate of production growth as compared to the that of population growth. But today the inconsistency of this approach has become absolutely clear. "... Thanks to the biased "sciences" of forecasting, econometrics, and statistics, if you bomb a city and then rebuild it, the data shows a huge spike in economic growth." [8].

\section{Conclusion}

In conclusion, let us remember the words by John Maynard Keynes from his work "The Great Slump of 1930": "We have involved ourselves in a colossal muddle, having blundered in the control of a delicate machine, the working of which we do not understand. The result is that our possibilities of wealth may run to waste for a time - perhaps for a long time."

Today the world based on this model of economic growth has come to its civilisational impasse as, against the background of the destruction of traditional values, the globalization of all socio-economic and sociopolitical processes, and the disappearance of national borders and features, there have formed atomized societies considering unrestrained consumption to be the main value - not 'usage', which means acquiring and using the necessary and sufficient amount of something with the aim of satisfying one's needs, but exactly 'consumption', which is focused on things that are needless and excessive. The basis for the stimulation of unbridled consumer demand was provided by consumer lending; there was a shift from maintaining consumer demand by means of employment and earned income to maintaining it by means of constant lending. A society based on material and status-related values, as opposed to collective traditional spiritual values, relies on fundamental contradictions. Economy, as the material basis of the existence of society, fuelled exclusively by credit fuel, is a detonator of these contradictions. Today, against the backdrop of aggravation of these contradictions and the exhaustion of the possibilities for economic growth achievable by means of these instruments (credit and consumer demand), the declared concepts and programmes of sustainable human development crash against insurmountable obstacles. This is due to the fact that concepts lying in the basis of development are totally different from those underlying growth. As a notion, economic growth is not identical to economic development. So, what does the modern humanity need: growth at any cost or development for the benefit of the current and future generations?

\section{Acknowledgements}

The author would like to thank Galina Barysheva, Igor Ardashkin, Angelika Lukashova and the anonymous referees for their constructive and useful comments on the paper. 


\section{References}

1. Xenophon of Athens. Sokraticheskie sochineniya [Socratic dialogues] (Moscow: Mir knigi, Literatura Publ., 2007)

2. Francisco Ibarra, Olga Korovina, Marcos Baez, Galina Barysheva, Maurizio Marchese, Luca Cernuzzi, Fabio Casati, "Tools Enabling Online Contributions by Older Adults", IEEE Internet Computing (PrePrints PrePrints)

3. G. Barysheva, I. Kashchuk, Procedia Soc. Behav. Sci., 166, 62-68 (2015)

4. M. Yacyno, Kul'tura indvividualizma [Culture of individualism] (Kharkov: Gumanitarnyy tsentr Publ., 117, 2012)

5. N.N. Zyazeva Rossiyskiy vneshneekonomicheskiy vestnik. Tribuna molodykh uchenykh. [The Russian Foreign Economic Activities Herald], 4, 106-116 (2013)

6. United Nations Millennium Declaration. Resolution adopted by the General Assembly United Nations A/RES/55/2, 18 September 2000, Fifty-fifth session, Agenda item 60 (b)

7. K. Marx, F. Engels, Sochineniya (Moscow: Gosudarstvennoe izdatel'stvo politicheskoy literatury Publ., 770, 1960)

8. J. Perkins, Ispoved' ekonomicheskogo ubiytsy [Confessions of an Economic Hit Man] (Moscow: Pretekst Publ., 319, 2014)

9. S. Patterson, Kvanty. Kak volshebniki ot matematiki zarabotali milliardy $i$ chut' ne obrushili fondovyy rynok [The Quants: How a New Breed of Math Whizzes Conquered Wall Street and Nearly Destroyed It] (Moscow: ann, Ivanov i Farber Publ., 2014)

10. A. Deaton, The Great Escape: Health, Wealth and the Origins of Inequality. (Prinston University Press. , 2013)

11. D.H. Meadows, D.L. Meadows, J. Randers, Predely rosta. 30 let spustya (Predely rosta. Doklad po proektu Rimskogo kluba «Slozhnye polozheniya chelovechestva» [Limits to Growth: The 30-Year Update (The Limits to Growth: a report for the Club of Rome's project on the predicament of mankind)] (Moscow: Binom. Laboratoriya znaniy Publ., 2015)

12. J. A. Schumpeter, Teoriya ekonomicheskogo razvitiya. Kapitalizm, sotsializm $i$ demokratiya [Theorie der wirtschaftlichen Entwicklung. Capitalism, Socialism and Democracy] (Moscow: Eksmo Publ., 2007)

13. J. M. Keynes, Obshchaya teoriya zanyatosti, protsenta $i$ deneg [The General Theory of Employment, Interest and Money] (Moscow: Gelios ARV Publ., 2012)

14. H. Lyndon, Jr. LaRouche, Currency Profiteer journal. Rubrika "Portrety" [Heading "Portraits"], November issue, 15-17 (2001)

15. V. V. Leont'ev, Ekonomicheskie esse. Teorii, issledovaniya, fakty $i$ politika [Economic essays. Theories, studies, facts, and politics] (Moscow: Politizdat Publ, 1990)
16. V. V. Leont'ev, Izbrannye stat'i. [Selected articles] (Saint-Petersburg: Izdatel'stvo gazety "Nevskoe vremya" Publ., 16, 1994)

17. J. K. Galbraith, Ekonomika nevinnogo obmana [The Economics of Innocent Fraud] (Moscow: Evropa Publ., 2009)

18. S. Yu. Glaz'ev, O vneshnikh i vnutrennikh ugrozakh ekonomicheskoy bezopasnosti Rossii v usloviyakh amerikanskoy agressii [About external and internal threats to the economic security of Russia in conditions of American aggression] Doklad akademika S. Yu. Glaz'eva v RAN [Report of the Academician S.Yu. Glaz'ev in the Russian Academy of Science] (2014) 